\title{
UJI TINGKAT KESUKAAN NUGGET IKAN MADIDIHANG (Thunnus albacares) DENGAN BAHAN PENGISI YANG BERBEDA
}

\author{
Ahmad Thalib \\ Staf Pengajar FAPERTA UMMU-Ternate, e-mail: madoks75@yahoo.co.id
}

\begin{abstract}
ABSTRAK
Nugget ikan merupakan salah satu produk diversifikasi berbahan baku daging ikan yang digiling dengan penambahan bumbu-bumbu dan dicetak, kemudian di lumuri dengan pelapis (coating dan breading) yang dilanjutkan dengan penggorengan. Pada dasarnya Nugget ikan sama dengan Nugget ayam hanya saja perbedaan terletak pada bahan baku yang digunakan. Nugget hasil olahan cita rasa yang enak, aman dan memenuhi kebutuhan zat gizi, sehingga penting untuk melakukan penelitian ini guna mengetahui perubahan mutu Nugget yang terjadi selama proses pengolahan. Penelitian ini dilakukan untuk mengetahui karakteristik terhadap mutu organoleptik Nugget ikan tuna madidihang. Tahapan yang dilakukan dalam penelitian ini adalah 3 (tiga) tahapan yaitu tahap persiapan sampel, tahap pengolahan, dan tahap uji organoleptik. Dari hasil penelitian uji tingkat kesukaan terhadap Nugget ikan madidihang dengan bahan pengisi tepung yang berbeda pada konsentrasi yang sama (30\%) memberikan pengaruh nyata terhadap semua parameter uji organoleptik yaitu yang terbaik adalah pada perlakuan tepung terigu dengan nilai rata-rata penampakan; 8,12, bau; 8,04, rasa ; 7,90 dan tekstur ; 7,56.
\end{abstract}

\section{Kata Kunci: Madidihang, Nugget ikan, Organoleptik}

\section{PENDAHULUAN}

\subsection{Latar Belakang}

Usaha diversifikasi produk ikan sangat diperlukan untuk memberikan pilihan bagi para pengolah. Diversifikasi pengolahan hasil perikanan dalam bentuk formulasi produk (diversifikasi). Hasil perikanan akhir-akhir ini telah menjadi perhatian dan berkembang dengan baik. Pengolahan hasil perikanan bertujuan untuk meningkatkan nilai tambah produksi, baik yang berasal dari penangkapan maupun akuakultur. Tujuan lainnya untuk mengenal produk perikanan ke pasaran dan diterima oleh konsumen secara luas (Fahrul, 2004).

Produk olahan perikanan begitu marak di pasaran untuk memenuhi kebutuhan protein bagi masyarakat. Hal ini disebabkan oleh kehidupan moderen yang serba sibuk dan banyak menyita waktu. Contoh produk olahan hasil perikanan yang siap saji adalah otak-otak, bakso ikan, Nugget ikan, fish finger, fish burger dan lain sebagainya. Produk olahan tersebut memiliki nilai gizi yang sangat tinggi dan dibutuhkan oleh tubuh. Salah satu produk olahan yang dipakai oleh masyarakat kelas menengah adalah Nugget (Burhan, 2004).

Nugget ikan merupakan salah satu makanan baru, dibuat dari daging ikan yang digiling dengan penambahan bumbu-bumbu dan dicetak, kemudian dilumuri dengan pelapis (coating dan breading) yang dilanjutkan dengan penggorengan. Pada dasarnya Nugget ikan sama dengan Nugget ayam hanya saja perbedaan terletak pada bahan baku yang digunakan. Nugget hasil olahan cita rasa yang enak, aman dan memenuhi kebutuhan zat gizi, sehingga penting untuk mengetahui perubahan mutu yang terjadi selama pemasakan (Mesra, 1994).

Salah satu upaya agar Nugget dapat dijangkau oleh semua kalangan masyarakat yaitu dengan menurunkan biaya produksi Nugget dengan cara memodifikasi bahan pengisi Nugget dengan mengganti bahan baku yang biasa digunakan dalam pembuatan Nugget. Pada proses pembuatan Nugget, bahan pengisi yang digunakan adalah tepung tapioka, tepung 
maizena dan tepung terigu. Kurangnya informasi tentang mutu Nugget dari bahan pengisi yang berbeda, maka penulis termotivasi untuk melakukan penelitian dengan judul "Uji Tingkat Kesukaan Nugget Ikan Madidihang (Thunnus albacores) dengan Bahan Pengisi yang Berbeda" terhadap Mutu Organoleptik Nugget Ikan.

\subsection{Tujuan dan Manfaat Penelitian}

Penelitian ini bertujuan untuk mengetahui karakteristik terhadap mutu organoleptik Nugget ikan tuna madidihang. Sedangkan manfaat dari penelitian ini diharapkan dapat memberikan informasi ilmiah tentang mutu Nugget yang dihasilkan kepada masyarakat khususnya pengolah produk Nugget yang menggunakan bahan pengisi yang berbeda.

\section{METODOLOGI PENELITIAN}

\subsection{Waktu dan Tempat}

Penelitian ini dilaksanakan pada bulan Juli sampai Agustus 2010 bertempat di Laboratorium Teknologi Hasil Perikanan (THP) Kampus A Universitas Muhammadiyah Maluku Utara (UMMU) Kelurahan Sasa Kota Ternate Selatan.

\subsection{Alat dan Bahan}

Bahan yang digunakan dalam penelitian ini adalah daging putih ikan madidihang (Thunnus albacores), tepung tapioka, tepung maizena, tepung terigu, bawang bombay, royco, garam, lada, serpihan air es, susu skim, putih telur dan minyak goreng secukupnya.

Adapun alat-alat yang akan dipakai adalah kompor, alat penggoreng, alat pengukus, timbangan analitik, loyang, sendok, talenan, plastik tahan panas, stop watch, peralatan untuk uji tingkat kesukaan dan alat tulis menulis.

\subsection{Prosedur Penelitian}

Adapun prosedur dalam pembuatan Nugget ikan madidihang $100 \mathrm{~g}$ yang meliputi tahapan penyiapan bahan baku sebagai berikut :

a. Daging ikan madidihang dibersihkan dari tulang, dan bagian lainnya yang tidak diinginkan.

b. Daging ikan dicuci hingga bersih dan haluskan dengan gilingan daging.

c. Dicuci kembali dengan menggunakan air yang telah didinginkan dengan suhu $5^{\circ} \mathrm{C}$ dilanjutkan dengan pengepresan daging ikan.

d. Campur hasil gilingan ikan dengan bumbu (bawang $250 \mathrm{~g}$, garam $2 \mathrm{~g}$, lada $5 \mathrm{~g}$, Royco
$240 \mathrm{~g}$ ) yang sudah dihaluskan dengan penambahan bahan pengisi tepung tapioka $30 \%$, maizena $30 \%$ dan tepung terigu $30 \%$.

e. Pencetakan Nugget di lakukan dengan menggunakan alat untuk pembuatan roti yang berbentuk persegi empat (olesi minyak dan lapisi plastik).

f. Pengukusan selama 30 menit sampai matang diangkat dan ditiriskan.

g. Di lakukan selanjutnya hasil pemotongan dicelup dalam putih telur.

h. Kemudian di lakukan pengorengan dalam kondisi minyak yang panas.

i. Nugget siap saji.

Proses pembuatan Nugget ikan madidihang dalam penelitian ini dapat dilihat pada Gambar 1.

\subsection{Prosedur Pengujian}

3.4.1. Uji organoleptik (Soekarto dan Hubeis, 2000)

Dalam penelitian ini, mutu organoleptik Nugget ikan madidihang yang diamati adalah: penampakan, bau, rasa dan tekstur. Pengujian terhadap penampakan, bau, rasa dan tekstur menggunakan dari angka 1-9. Pengujian dilakukan 25 orang panelis tidak terlatih.

\subsection{Rancangan Percobaan dan Analisis Data}

Penelitian ini menggunakan Rancangan Acak Lengkap (RAL) faktor tunggal dengan 3 taraf/perlakuan yaitu tepung tapioka $30 \%$, tepung maizena $30 \%$, dan tepung terigu $30 \%$. Masingmasing perlakuan di ulang sebanyak 3 kali. Rumus rancangannya adalah sebagai berikut (Sastrosupadi, 1994) :

$$
y_{i J}=\mu+\alpha i+\sum i J ; i=1,2,3, \ldots t ; j=1,2,3 \ldots r
$$

Dimana :

$$
\begin{array}{ll}
y_{i j} \quad: \text { Respon suatu percobaan ke-i, ulangan } \\
\quad \text { ke-j } \\
\mu \quad: \text { Nilai tengah umum } \\
\alpha i \quad: \text { Pengaruh perlakuan jenis bahan } \\
\quad \text { pengisi ke-i ( } \alpha=\mathrm{A}: \text { tepung tapioka, } \\
\quad \text { B : tepung maizena, } \mathrm{C}: \text { tepung terigu }) \\
\sum i j: \text { Galat percobaan }
\end{array}
$$

Hasil pengamatan, akan di olah menggunakan Analisis Ragam. Jika uji berpengaruh/berbeda nyata, maka akan di lanjutkan dengan uji lanjut Duncan. 


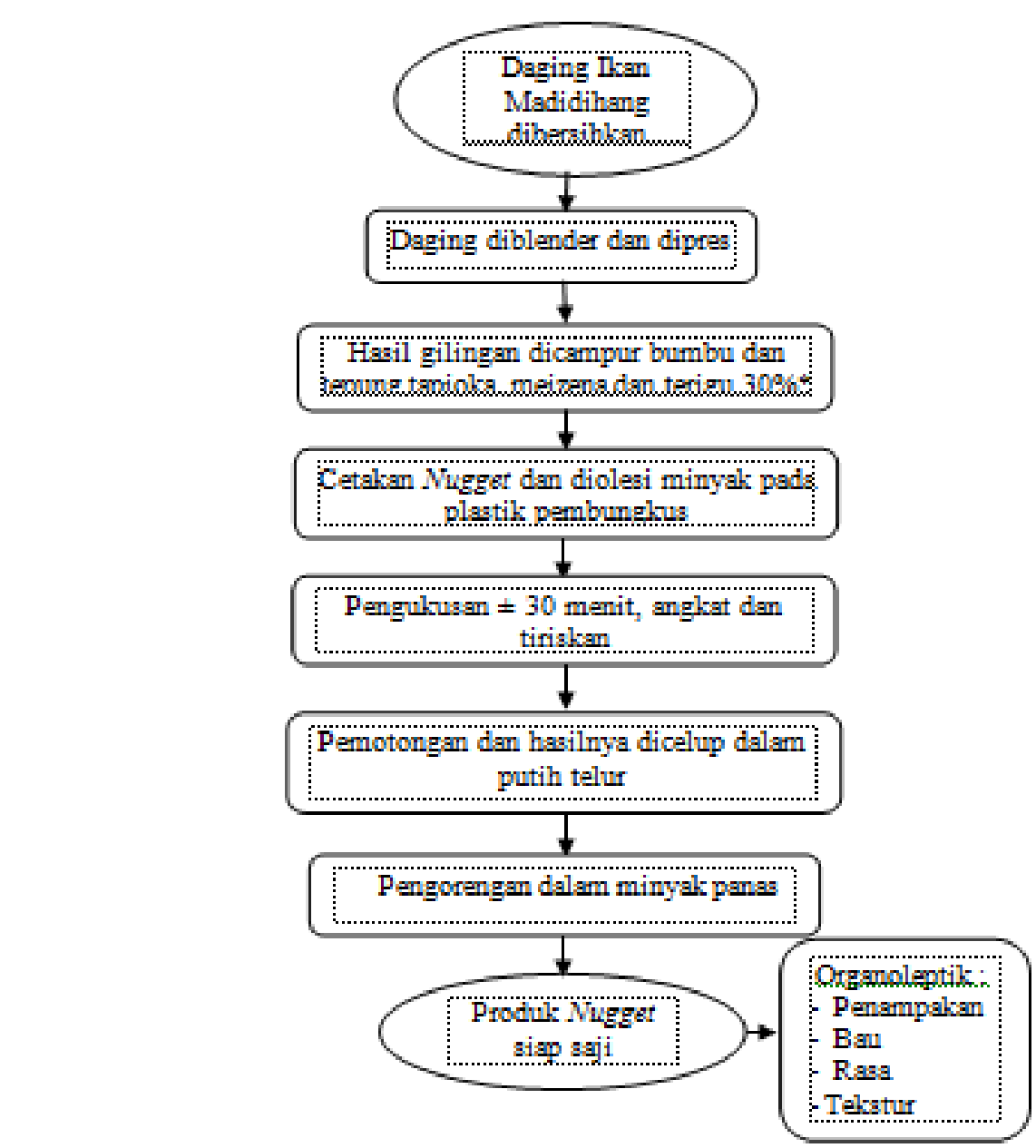

Keterangan : * Bagian yang dimodifikasi

Gambar 1 : Diagram alir proses pembuatan Nugget ikan madidihang Sumber Nugget Ikan (Yuniardo, 1995)

\section{HASIL DAN PEMBAHASAN}

Organoleptik merupakan suatu cara untuk mengevaluasi kualitas makanan melalui panca indera manusia, cara ini digunakan untuk menilai kualitas makanan yang diuji menggunakan salah satu organ panca indera. Uji ini dapat dilakukan untuk mengetahui penerimaan panelis terhadap suatu produk yang dihasilkan (Soekarto dan Hubeis, 2000) hasil uji organoleptik Nugget ikan madidihang yang dilakukan meliputi parameter, penampakan,bau, rasa dan tekstur. Karakteristik organoleptik Nugget ikan madidihang dapat di lihat pada Tabel 1.

\subsection{Penampakan}

Karakteristik pertama yang dinilai konsumen dalam mengkonsumsi suatu produk adalah penampakan produk itu baik atau tidak, karena sifat mutu komoditas di nilai dengan penglihatan seperti bentuk, ukuran, dan warna (Soekarto, 1990).
Hasil pengujian organoleptik penampakan Nugget ikan Madidihang dengan menggunakan jenis bahan pengisi yang berbeda disajikan pada Gambar 2.

Dari Gambar 2, menunjukkan bahwa nilai tertinggi diperoleh pada perlakuan $\mathrm{C}$ (tepung terigu $30 \%$ ) dengan nilai 8,12 yang berarti tidak berongga, warna putih susu/cokelat, nilai terendah diperoleh pada perlakuan B (tepung maizena 30\%) dengan nilai 6,50 yang berarti sedikit berongga, warna putih $\mathrm{krem} /$ cokelat, sedangkan pada perlakuan A (tepung tapioka $30 \%$ ) memperoleh nilai 6,92 yang berarti sedikit berongga warna putih $\mathrm{krem} /$ cokelat.

Hasil analisis ragam menunjukkan bahwa setiap perlakuan bahan pengisi memberikan pengaruh nyata terhadap penampakan pada Nugget ikan madidihang. Hasil uji lanjut Duncan menunjukkan bahwa perlakuan A (tepung tapioka $30 \%$ ), berbeda nyata dengan perlakuan B (tepung 
maizena 30\%) dan berbeda nyata dengan perlakuan $\mathrm{C}$ (tepung terigu $30 \%$ ).

Berdasarkan Gambar 2 terlihat bahwa terjadi kenaikan pada konsentrasi $30 \%$ dengan spesifikasi warna putih/krem diduga karena adanya bahan pengisi berupa tepung yang di tambahkan ke dalam proses pembuatan Nugget.
Warna cokelat diduga akibat proses pemasakan (penggorengan) yang di lakukan. Hal ini sesuai dengan pendapat de Man (1997) bahwa warna yang diperoleh disebabkan oleh reaksi pencokelatan/Maillard yang terjadi yaitu reaksi susu pereaksi dalam bahan pengikat (pengisi) yaitu tepung maizena.

Tabel 1. Karakteristik organoleptik Nugget ikan madidihang

\begin{tabular}{ccccc}
\hline \multirow{2}{*}{ Jenis tepung } & \multicolumn{4}{c}{ Rata-rata / Parameter } \\
\cline { 2 - 5 } & Penampakan & Bau & Rasa & Tekstur \\
\hline Tapioka 30\% & 6,92 & 6,72 & 6,90 & 6,81 \\
Maizena 30\% & 6,50 & 6,52 & 6,54 & 6,49 \\
Terigu 30\% & 8,12 & 8,04 & 7,90 & 7,56 \\
\hline
\end{tabular}

\subsection{Bau}

Salah satu faktor yang menentukan mutu suatu makanan dapat diterima oleh konsumen adalah bau. Bau makanan menentukan kelezatan makanan tersebut (Winarno, 1991). Bau merupakan senyawa yang berperan dalam peptitein, asam amino, hidrogen sulfat, metil markeptin (pembusuk). Hasil pengujian organoleptik bau Nugget ikan madidihang dengan menggunakan jenis bahan pengisi yang berbeda disajikan pada Gambar 3.

Gambar 3 menunjukkan terjadinya perbedaan nilai bau pada setiap perlakuan bahan pengisi tepung, dimana nilai tertinggi di proses pada perlakuan bahan pengisi tepung terigu $30 \%$ dengan nilai 8,04 yang berarti baunya tidak amis, spesifik Nugget ikan, sedangkan nilai terendah di peroleh pada perlakuan bahan pengisi tepung maizena $30 \%$ dengan nilai 6,52 yang berarti baunya tidak amis, spesifik Nugget ikan berkurang. Pada perlakuan bahan pengisi tepung tapioka $30 \%$ di peroleh nilai 6,72 yang berarti tidak amis, spesifik Nugget ikan sedikit berkurang.

Hasil analisis ragam menunjukkan perlakuan penambahan tepung sebagai bahan pengisi pada pembuatan Nugget memberikan pengaruh nyata. Hasil uji lanjut Duncan menunjukkan bahwa perlakuan $\mathrm{C}$ bahan pengisi tepung terigu $30 \%$ berbeda nyata dengan perlakuan A (tepung tapioka) dan B (tepung maizena).

Berdasarkan Gambar 3 terlihat bahwa terjadi kenaikan pada konsentrasi $30 \%$. Hal ini diduga bahwa bau Nugget yang di hasilkan selama penggorengan (pemasakan) dan penambahan tepung dan bumbu-bumbu berupa rempah-rempah (royco, garam, bawang bombai, susu dan lada) dapat menghilangkan bau amis ikan sebagai bahan baku dan memberi cita rasa khas pada bau Nugget.

Hal ini sesuai dengan uraian Matz (1978) bahwa tepung merupakan komponen pembentuk cita rasa karena tingginya kandungan protein yang ada dalam bahan pangan akan menyebabkan bau, tekstur dan penampakan yang khas. Lebih lanjut Winarno (1997) menambahkan bahan garam merupakan komponen bahan makan yang ditambahkan dan digunakan sebagai penyedap cita rasa dan sebagai pengawet. Selain itu menurut Palungkun dan Budiarti (1992), bawang bombai berfungsi sebagai penambah bau dan untuk meningkatkan cita rasa produk yang dihasilkan.

\subsection{Rasa}

Rasa merupakan salah satu yang mempengaruhi nilai penerimaan seseorang terhadap suatu makanan. Penerimaan panelis terhadap rasa dipengaruhi oleh beberapa faktor antara lain senyawa kimia, suhu, konsentrasi dan interaksi dengan komponen lainnya (Winarno, 1991).

Hasil pengujian organoleptik rasa Nugget ikan madidihang dengan menggunakan jenis dan bahan pengisi yang berbeda dengan konsentrasi yang sama (30\%) seperti terlihat pada Gambar 4.

Berdasarkan Gambar 4 terlihat bahwa, nilai rasa Nugget ikan madidihang tertinggi diperoleh pada perlakuan A (tepung terigu 30\%) dengan nilai 7,90 yang berarti enak, rasa ikan dominan. Sedangkan nilai terendah di peroleh 
pada perlakuan B (tepung maizena 30\%) dengan nilai 6,54 yang berarti enak, rasa ikan sedikit berkurang.

Hasil analisis ragam menunjukkan bahwa perlakuan penambahan tepung sebagai bahan pengisi memberikan pengaruh nyata terhadap nilai rasa Nugget ikan madidihang. Hasil uji lanjut Duncan menunjukkan bahwa perlakuan penambahan tepung terigu $30 \%$ (C) berbeda nyata dengan perlakuan pada tepung tapioka (A) dan tepung maizena (B).

Rasa enak dan rasa ikan yang dihasilkan di duga berkaitan dengan garam yang ditambahkan dan kandungan asam amino yang dimiliki daging ikan madidihang serta proses pemasakan (penggorengan) yang menghasilkan senyawa pemberi cita rasa, dimana selama pemasakan menyebabkan meresapnya garam yang berfungsi sebagai pemberi cita rasa. Menurut Lechninger (1993), Rahayu dan Nasran (1995); Shahidi (1998), bahwa rasa enak dan agak enak dipengaruhi oleh komponen utama yaitu peptida dan asam amino yang terdapat pada daging ikan. Rasa enak dipengaruhi oleh asam amino glutamat dan aspartat (Ijong dan Ohta, 1995).

Hadiwiyoto (1993) menambahkan bahwa rasa ikan disebabkan oleh reaksi-reaksi biokimia yang terjadi pada daging ikan. Selain itu rasa khas ikan dihasilkan oleh senyawa-senyawa volatil dan senyawa non volatil. Senyawa volatil yang berperan yaitu karbon dan alkohol (tunnan asam lemak bebas), sulfur, bromfenol dan hidrokarbon, sedangkan senyawa non volatil yang berperan adalah senyawa yang mempunyai berat molekul (BM) rendah yaitu senyawa nitrogen (asam amino bebas, peptida, nukleotida dan basa organik).

Rasa ikan sedikit berkurang pada Nugget ikan madidihang diduga lebih dipengaruhi oleh bahan tambahan lain seperti bawang, lada dan bahan pengikat (pengisi) seperti tepung sehingga rasa ikan menjadi berkurang. Hal ini menurut Matz (1978) bahwa tepung merupakan komponen pembentuk cita rasa karena tingginya kandungan protein dan karbohidrat yang ada dalam bahan pangan akan menyebabkan bau dan rasa yang khas pada produk.

\subsection{Tekstur}

Tekstur merupakan salah satu faktor yang mempengaruhi pilihan konsumen terhadap suatu bahan pangan. Tekstur adalah kehalusan suatu irisan pada waktu disentuh dengan jari oleh panelis (Winarno, 1991).

Hasil pengujian organoleptik tekstur Nugget ikan madidihang dengan menggunakan jenis dan bahan pengisi yang berbeda dengan konsentrasi yang sama dapat disajikan pada Gambar 5.

Gambar 5 menunjukkan bahwa nilai tekstur Nugget ikan madiihang tertingi di peroleh pada bahan pengisi $\mathrm{C}$ (tepung terigu 30\%) dengan nilai 7,56 yang berarti padat, kompak, agak kenyal. Sedangkan nilai terendah di peroleh pada Nugget dengan bahan pengisi B (tepung maizena 30\%) dengan 6,49 yang berarti agak padat, agak kompak, kurang kenyal. Pada perlakuan bahan pengisi A (tepung tapioka 30\%) dengan nilai 6,81 yang berarti padat, kompak, agak kenyal.

Hasil analisis ragam menunjukkan bawa perlakuan bahan pengisi tepung yang berbeda memberikan pengaruh nyata pada nilai tekstur Nugget ikan madidihang. Hasil uji Duncan menunjukkan bahwa perlakuan pada bahan pengisi tepung terigu berbeda nyata dengan perlakuan pada bahan pengisi tepung tapioka dan tepung maizena, begitu sebaliknya bahan pengisi tepung tapioka tidak berbeda nyata dengan bahan pengisi tepung maizena.

Kompak, agak kenyal dan padat pada Nugget ikan madidihang di duga lebih dipengaruhi oleh tepung yang di jadikan sebagai bahan pengisi mengandung pati. Selain itu kekompakan dan kekenyalan bisa di pengaruhi juga oleh lamanya pemasakan (penggorengan), dan minyak yang digunakan saat penggorengan Nugget. Hal ini menurut Potter (1973) pati yang dikandung dalam Nugget pada saat di goreng tergelatinasi dengan sempurna dan mengakibatkan tekstur yang dihasilkan keras dan elastis (kenyal). Selain itu juga Nugget menggunakan bahan pengisi yang lebih banyak sehingga dapat mengadsorpsi lebih banyak jumlah emulsifier yang lebih sedikit sehingga menyebabkan keras/padat. 


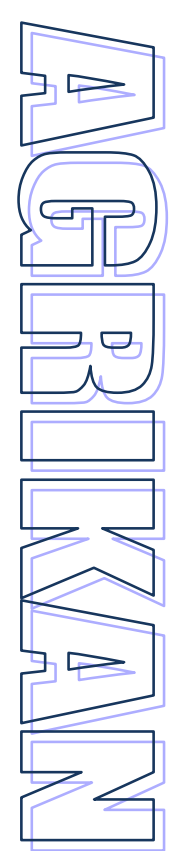

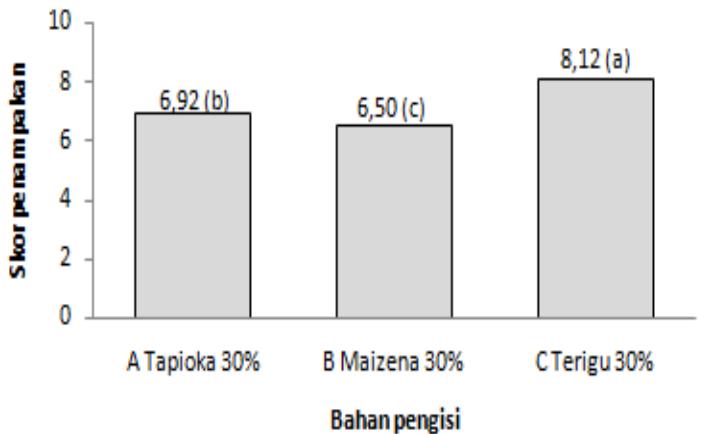

Keterangan : Angka-angka pada diagram batang yang diikuti huruf superscripts berbeda $(a, b, c)$ menunjukan hasil yang berbeda nyata pada uji Duncan pada taraf nyata $95 \%$

Gambar 2. Nilai rata-rata penampakan Nugget ikan madidihang

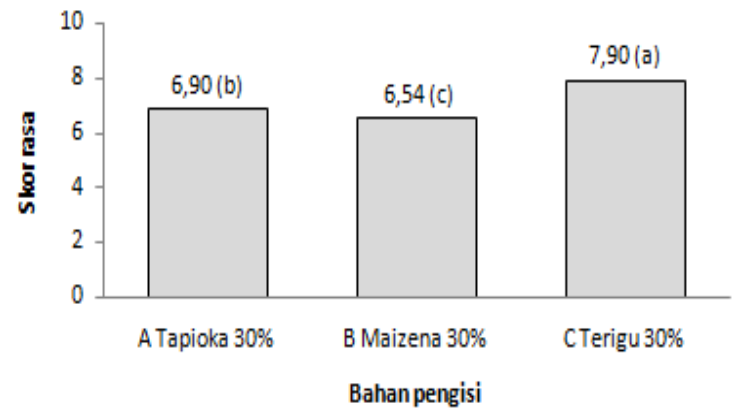

Keterangan : Angka-angka pada diagram batang yang diikuti huruf superscripts berbeda $(a, b, c)$ menunjukan hasil yang berbeda nyata pada uji Duncan pada taraf nyata $95 \%$

Gambar 4. Nilai rata-rata rasa Nugget ikan madidihang

\section{PENUTUP}

\subsection{Kesimpulan}

1. Dari hasil penelitian uji tingkat kesukaan terhadap Nugget ikan madidihang dengan bahan pengisi tepung yang berbeda pada konsetrasi yang sama (30\%) memberikan pengaruh nyata terhadap semua parameter uji organoleptik yaitu: penampakan, bau, rasa dan tekstur.

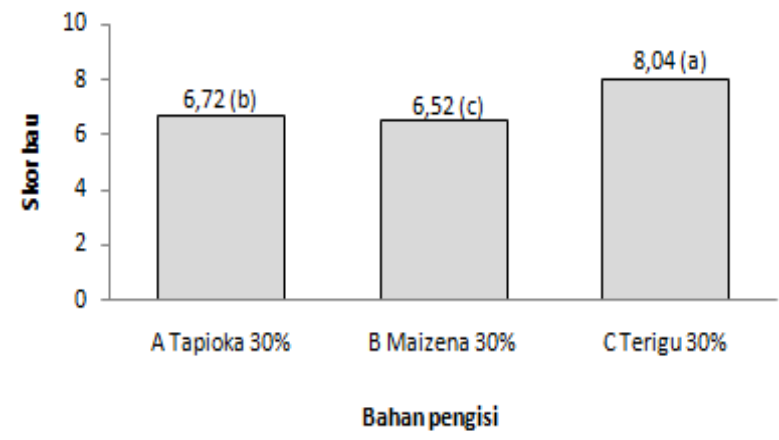

Keterangan : Angka-angka pada diagram batang yang diikuti huruf superscripts berbeda $(a, b, c)$ menunjukan hasil yang berbeda nyata pada uji Duncan pada taraf nyata $95 \%$

Gambar 3. Nilai rata-rata bau Nugget ikan madidihang

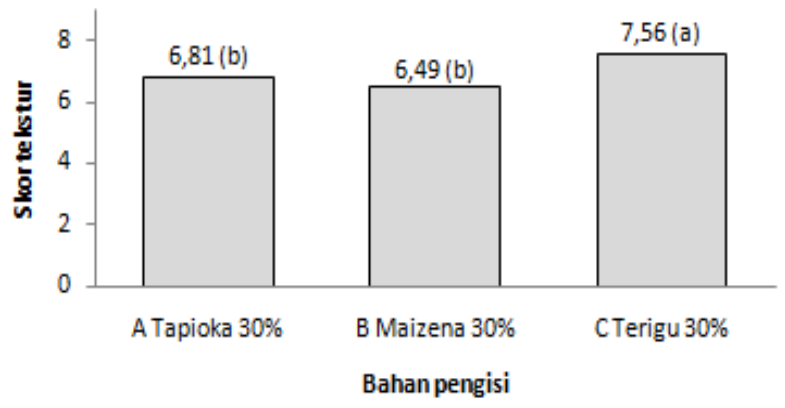

Keterangan : Angka-angka pada diagram batang yang diikuti huruf superscripts berbeda $(a, b)$ menunjukan hasil yang berbeda nyata pada uji Duncan pada taraf nyata 95\%

Gambar 6. Nilai rata-rata tekstur Nugget ikan madidihang

2. Bahan pengisi terbaik pada Nugget ikan madidihang di peroleh pada perlakuan tepung terigu dengan nilai rata-rata penampakan 8,12 , bau 8,04, rasa 7,90 dan tekstur 7,56.

\subsection{Saran}

Perlu adanya penelitian lanjutan tentang uji kimia dan mikrobiologi untuk mengetahui mutu Nugget ikan madidihang yang dihasilkan.

\section{DAFTAR PUSTAKA}

Budiarti A. 1992. Bawang Putih Dataran Rendah. Penebar Swadaya, Jakarta.

Burhan. 2004. Panduan praktis memilih dan menangani produk perikanan. Penerbit PT. Gramedia Pustaka Utama, Jakarta.

de Man TM. 1977. Kimia Pangan Institut Teknologi Bandung, Bandung.

Fahrul. 2004. Pembuatan fish nugget dari ikan mas (Cyprinus carpio). PAPER . Departemen Teknologi Pasca Panen Sekolah Pasca Sarjana Institut Pertanian Bogor.

Hadiwiyoto S. 1993. Teknologi Hasil Perikanan. Jilid 1, Yogyakarta ; Penerbit Liberty. Halaman : 138 $-139$. 
Ijong FG dan Ohta Y. 1995. Armino Acid Composition of Bakasang, Tradisional Fermented Fish Sauce. Journal of Bioscience and Bioengineering.

Lechninger AL. 1993. Dasar-dasar biokimia. Jilid 2. Thenawidjaja N. Penerjemah. Terjemahan dari Principles of Biochemistry. Jakarta; penerbit Erlangga.

Matz SA. 1978. Cookies and Cracker Tecnology. The AVI Publishing Co. Inc, Westport, Conecticut.

Mesra. 1994. Chicken Nugget dan Shrimp Nugget. Buletin hero, mei 1994. Jakarta.

Rahayu S dan Nasran S. 1995. Ikan Kayu ( Katsuobushi ) Sebagai Penyedap Masakan. Jakarta ; LIPI Prosiding Widya Karya Nasional Khasiat Makanan Tradisional.

Sastrosupadi A. 1994. Rancangan Percobaan Praktek. Untuk Bidang Pertanian.

Soekarto ST dan Hubeis M. 2000. Metodologi Peneletian Organoleptik. Petunjuk Laboratorium, Bogor ; Pusat Antar Universitas Pangan dan Gizi, Program Studi Ilmu Pangan, Institut Pertanian Bogor.

Soekarto ST. 1990. Dasar-dasar Standarisasi dan Pengawasan Mutu Pangan. Pusat Antar Universitas, Institut Pertanian Bogor. Bogor

Winarno FG. 1991. Pangan dan Gizi. Gramedia Pustaka Utama, Jakarta.

1997. Dasar Teknologi Pangan. Bogor ; Fakultas Teknologi dan Mekanisasi Pertanian, Institut Pertanian Bogor.

Yuniardo N. 1995. Resep Nugget Ikan. InfoResep.com inforesep.com/resep-Nugget ikan.html Tembolok - Mirip. 